News and views

\title{
Application of Geophysical Methods in the Investigation of Possible Lochs in the Town of Miroslav
}

\author{
Pavlína Valováa, ${ }^{\mathrm{a}, \mathrm{b}^{*}}$, Věra Glisníkovác, \\ ${ }^{a}$ GEODRILL s.r.o., Bělohorská 2115/6, 62100 Brno, Czech Republic \\ ${ }^{b}$ Institute of Geological Sciences, Faculty of Science, Masaryk University, Kotlářská 2, 61137 Brno, Czech Republic \\ 'University of Technology, Faculty of Civil Engineering, Veveři 331/95, 60200 Brno, Czech Republic \\ ${ }^{d}$ VENTIMIGLIA s.r.o., 1321/29a, 62100 Brno, Czech Republic
}

ARTICLE INFO

\section{Article history:}

Received: 10 December 2010

Accepted: 20 January 2011

\section{Keywords:}

loch

geophysical research

collapse

cavern

\section{A B STRACT}

During Christmas 2002 the pavement of a yard caved-in, at a private home in the town of Miroslav. The cave-in exposed a cavern under the pavement, $1.5 \mathrm{~m}$ in diameter and $6 \mathrm{~m}$ deep. Investigation confirmed the hole had opened with the gradual subsidence of soil into the cavern. Indirect evidence resulting from subsequent research supports the possibility that a loch existed here in the past, which, at a later date had been turned into a wine cellar.

\section{Introduction}

The word loch (from German "loch", meaning "hole") is used in Czech archaeology to denote a Medieval or Early Modern period cellar or tunnel, dug into a rock or sandstone massif. These cellars served various functions, including hiding places in times of danger, or more usually for storing food because of their constant cool temperature. In Moravia lochs are frequently built during hillside sand mining, and subsequently used as cellars.

After the cave-in of part of a yard of a family house (Figure 1), situated at the northern limit of the town of Miroslav, geophysical and sounding investigations were carried out in an effort to detect the existence of similar objects in this part of the town.

\section{Methodology of the research}

Soundings were conducted in the cavern itself (Figure 2) and its proximity. Georadar profiles were developed on the yard's

"Corresponding author. E-mail: pavlina@geodrill.cz margins and within the built-up area. The aim was to detect ruins and to determine the shape of the original cavity. Sounding was performed with a $1.3 \mathrm{~m}$ driving (soil) rod, and a $4 \mathrm{~m}$ hand auger. Machine-digging was not possible in this location. The intended excavation to expose the cavity was not feasible for safety reasons.

Geophysical research was performed using ground penetrating radar (GPR), a type of electromagnetic reflex. High-frequency electromagnetic signals ( 8 to $4,000 \mathrm{MHz}$ ) are emitted by the apparatus from a source (dipole) sent into the environment being examined. The output is a time section. The depth range of GPR is between a few centimetres a several metres. However, the depth range varies greatly depending on frequency, conductivity of rocks in the environment (caused most often by mineralisation of water by which they are saturated, or by presence of clayey materials), and on the technical parameters of the measuring apparatus.

\section{Occurrence of lochs in Moravia}

Most Moravian lochs were built in the Medieval and Early Modern period. They appear rarely in the late Modern 


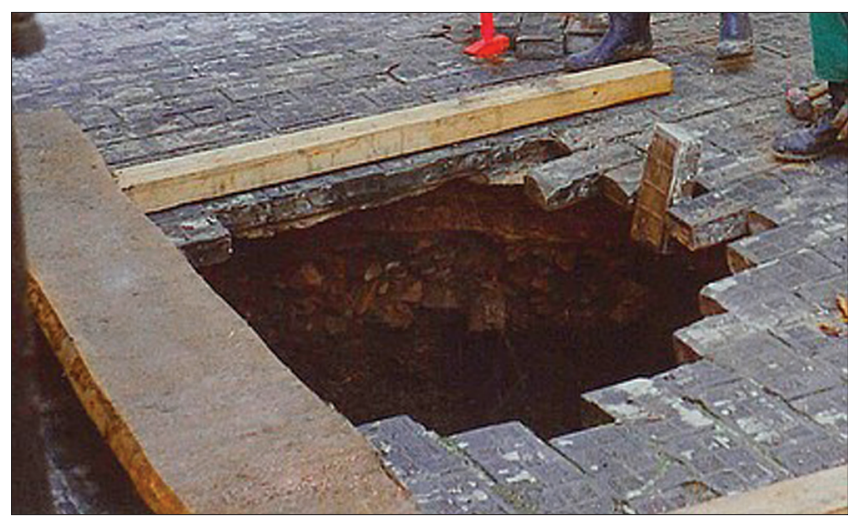

Figure 1. The hole at the location of the collapse.

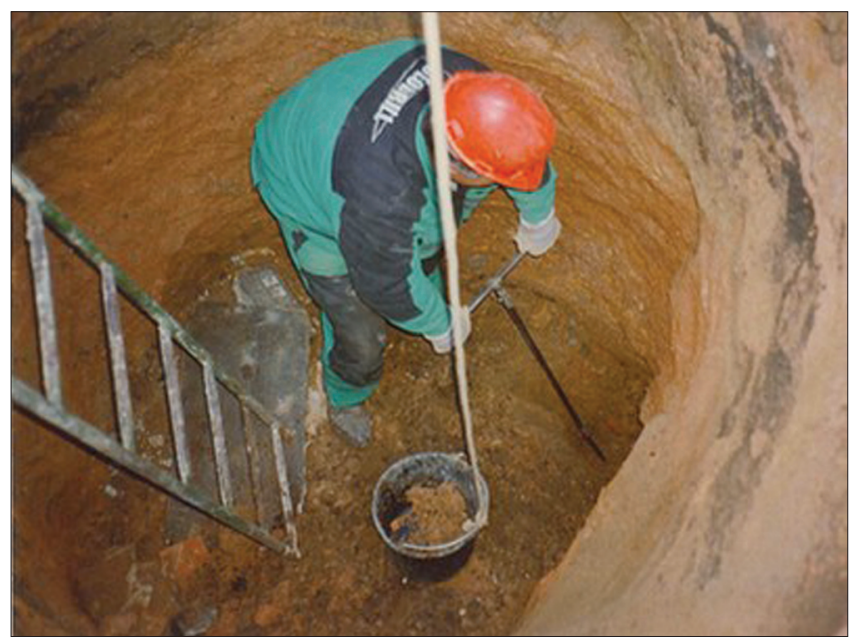

Figure 2. Detail of the works at the bottom of the cavern.

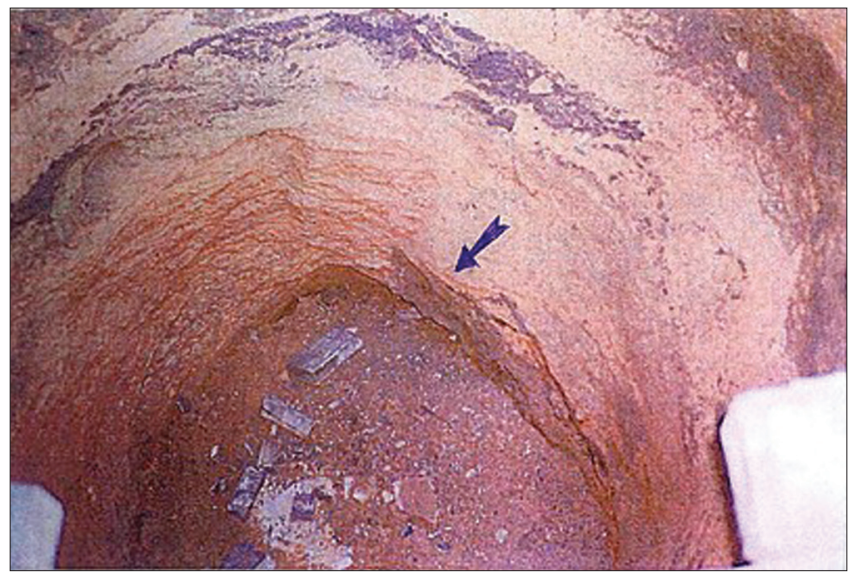

Figure 3. Profile of the cylindrical cavern at its bottom.

period, when they were mostly built for civilian and military defence purposes, especially during World War II. Lochs can be found today in many places in Moravia. Although not originally considered pre-medieval (Červinka 1905, 10-11; Černohorský 1941, 248; Unger 1987, 106), it has become apparent in the last few years, as research proceeds, that similar structures were significant in the Prehistoric period. Proof of this can be seen in the structures at Vojkovice near Brno (Kos 1995; Stuchlík 2000) or in Tišín in the city of Prostějov (Bálek et al. 2003). Their frequency in Moravia

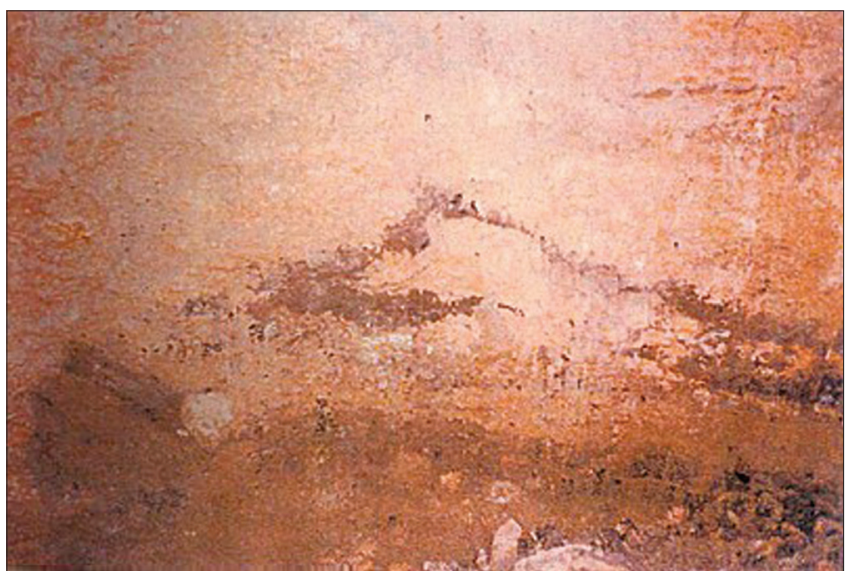

Figure 4. Detail at the bottom of the cavern.

\section{MIROSLAV - PF0}

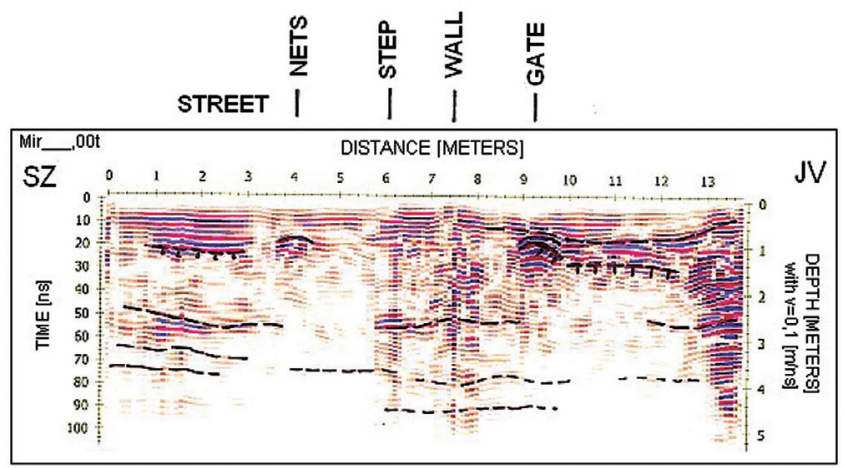

Figure 5. Time cut No. 0 NW-SE.

indicates a dependence on fertile areas (around the cities of Znojmo, Kyjov, Brno and Olomouc) which have been settled since the Early Medieval period. An important aspect of their location is the geological foundation, which must be suitable for digging these structures. Lochs were most often dug in loams, clays and rocks.

Lochs are found in approximately 126 localities in Moravia. This number probably does not correspond to the real number of lochs, but to the present state of research (Kos 2002b). In Austria and Bavaria research of loch-type underground cellars is common (Schwarzfischer 1990; Macek 1997/1998; Skutil 1949). In the Czech Republic whole systems of underground loch-type corridors are known in connection with the recent discovery of the ground plan of the medieval village of Mstěnice near Hrotovice (Nekuda 1992, Nekuda 2000). It is assumed that they were built by the $9^{\text {th }}$ century, even though they are characteristic of the type built at the turn of the $12^{\text {th }}$ and $13^{\text {th }}$ centuries. The researchers J. Skutil, Z. Měřínský, V. Nekuda and J. Unger brought forward the issue of the existence of lochs some time ago (Skutil 1948, 1949; Měŕínský 1977; Nekuda 1972; Unger 1987). E. Černý performed surface research in the Drahany Upland for many years (1992). Numerous cases of cave-in exposures of lochs were recorded there, and walled lochs identified. These structures were parts of homesteads or were found near 
or amongst them. In these places relatively deep hoppershaped earth falls occurred, reflective of walled cellars but possibly also of failed lochs. The number of finds of lochtype corridors has recently increased within the historical centres of cities.

\section{Collapse of the yard of a family house in the town of Miroslav}

In December 2002 the originally intact surface of the central part of the yard of a family house in the town of Miroslav, broke and sank under a relative of the house. A cylindrical cavity appeared, with a diameter of ca $1.5 \mathrm{~m}$ and height of $2.6 \mathrm{~m}$. However, in consideration of to the considerable firmness of the pavement, jointed by cement mortar, it is probable that this collapse was not caused immediately after subsidence of the overlaying material into an unknown cavity, but by the breakage of the yard pavement or of the uppermost layers under this paving. An opening of ca $1 \mathrm{~m}$ in diameter remained after removing the paving stones from the margins of the hole.

When the area was explored it was found out that the cave-in did not correspond to the outside context of the builtup area, by its directions nor by its size. The loch had the character of a narrow corridors lagged by a single line, and ran diagonally towards the foot-print of both the built-up area and the streets. Breaching and branching of the corridors is a frequent sign of this cellarage. The house and its inner yard do not have a basement, according to available information.

\section{Situation at the site of the collapse}

The house yard has a foot-print of $6 \times 6 \mathrm{~m}$ and is bounded by the house itself, together with its annexed building, wall, wicket and garden fencing. The yard was paved with concrete-chamotte paving of brick size and jointed by firmly compact cement mortar. The base consisted of a similar mortar ca $3 \mathrm{~cm}$ thick, laying atop relatively loose landfill containing sand, loam, fragments of bricks and burnt tiles with cobbles.

\section{Profile and description of the cavern}

The paving around the opening up to the distance of ca $60 \mathrm{~cm}$ (even on intact base) is somewhat deformed (we omitting the sloping of the yard surface towards the drain in the south corner of the yard). Base landfills level show signs of gradual subsidence including the existence of older layer of mortar, ca $2 \mathrm{~cm}$ thick, located approximately $20 \mathrm{~cm}$ under the present surface. The total thickness of the coarse landfill layer under the paving is ca 50 to $60 \mathrm{~cm}$. It can therefore be assumed that, even before the laying of the paving units about 50 years ago, the surface of the yard was sinking gradually in at its central part. In the cylindrical walls of the cavern (Figure 3), there is no cavity or a relic of a vault apparent. The cylindrical shape of the cavern itself is somewhat atypical, but since it is located in less cohesive soils with distinctive amount of coarser component, such shape is possible (it is sometimes documented also in narrow broken-through passageways). However, according to the amount of sunken (missing) material (ca 6 to $7 \mathrm{~m}^{3}$ ), the cavity must have been larger or much higher than regular corridor or passageway. The possibility of sinking of the backfill of an old well cannot be definitely excluded, but the well would have to be very deep (15 to $20 \mathrm{~m}$ ), due to empty volume after compression. There are no traces of digging or walling up apparent on the walls of the cavern. Under the abovementioned coarse landfills, other cultural layers are apparent down to the depth of ca $1.1 \mathrm{~m}$. It has prevailingly character of sandy loams, with ochre and grey to black layers. These loams probably come from the time of adaptation of the terrain for building purposes or may be even older. The base of the landfill consists of ochre Neogéne slope clayey loams with a coarsely sandy component. At the bottom of the cavern (Figure 4), reddish coarsely pebbly loams (redeposited basal clastics of the Boskovice Furrow) protrude on the NNE walls. The fracture plane on the clastics is clearly visible. It may be a relic of a wall of unvaulted cavity. In this place the talus cone is also further from the wall. The research was focused into this locality. Near the outcrop of the clastics, in the Neogéne soils, intervention into the layers up to the height of ca $30 \mathrm{~cm}$ from the bottom of the cavern is very apparent. The buried profile of an older cavity, obviously of anthropogenic origin, is also apparent. The thin upper layer of the backfill, evidently done from inside, consists of greasy carbons, probably a residue of decayed timber. The material of the backfill is formed by sandy rock with gray to black stripes. A typical small cavity, originating from the sinking of the backfill, is missing between the original soil and the top of the backfill. This small cavity, however, may have been reduced gradually by the abovementioned sinking of the soils, including the yard's surface.

\section{Research findings}

In the vicinity of the collapse, georadar profiles were developed, along the yard margins and the foot-print of the built-up area (Dostál 2003). Profile 0 (Figure 5) was obtained from the opposite wall across the street into the yard down to the drain. In cross-section it is possible to see reinforcement of the road and water supply line, a step of the sidewalk, peripheral wall, side reflection of the cellar entrance and the drain. The profile of the bottom of backfills is sunk, with irrelevant anomalies Profiles 1 to 3 were obtained along the circumference of the yard. It is possible to see the boundary line of landfills, side reflection of the cavity on the profile 3 : an indication of a buried corridor which corresponds to continuation of the buried corridor by the southeast wall across the cavern. Profile 4 was conducted on Údolní Street along the sidewalk margin, from the wall connecting the 
garage and the shed to the corner of the streets Údolní and Kostelní. At the beginning of the profile, the mains pipes to the shed and to the garage are visible, cellar vault, gas connection and other networks by the corner of the house are also clearly apparent. The boundary of the landfills on the original terrain is clearly distinguishable as well. A more complicated situation in the form of landfill layers exists at meters 21 to 24 . There is a recess and very slight manifestation of an anomaly that could represent the ceiling of a corridor in the depth of $2.6 \mathrm{~m}$, which roughly corresponds to the level of the buried corridor in the cavern. Profile 5 was conducted along the sidewalk of Kostelní Street from the corner of the house to approximately the middle of the next house. Boundary lines of the landfills are clearly apparent, as is a portion of the lower boundary line of the layers. Only a few inhomogeneities occur on the boundary line. However, a slight indication of a cavity at 15 to 17 metres is perceptible. It may be a connection but it could also be the infill of a depression on the original terrain. The direction, however, corresponds with an extension of the buried corridor from the cavern.

Diagonally oriented soundings with the driving rod exposed the existence of the remains of a cavity at the boundary of the buried corridor and broken-off clastics at the depth of $30 \mathrm{~cm}$ under the bottom level, at the distance of ca $0.5 \mathrm{~m}$ from the cavern wall. The cavity probably exceeds the range of the probing rod. The probe was directed towards the east. The rest of the probes detected only material of the talus cone (collapsed soil). However, it is almost certain that the cavern widens markedly under the talus cone. Steeply diagonal bores were concentrated by the north margin of the cavern, where there was the greatest probability of occurrence of a larger cavity. However, only loose material from the subsidence was found to a depth of $6.3 \mathrm{~m}(3.7 \mathrm{~m}$ from the bottom). Its thickness exceeds the range of the drilling rod. Underground water was not found, but the soils of the talus cone are markedly humid and plastic from $0.5 \mathrm{~m}$ and down. During the sounding, draught from the cavities was recorded constantly, from both the hole of the drilling rod and the soils that had moved away from the talus cone. The leaking air had a distinctly fuggy, even putrefactive odour of putrefying earth. The over narrow profile of the cavern prevented bring under a smaller angle, and when the drilling was being carried out from the yard surface, the total thickness of the soils exceeded the range of the auger. The auger drill rod tends to get under the talus diagonally, which confirms the existence of much wider cavity than would be the size of a corridor. Also crossing and branching of the corridors is possible.

\section{Discussion}

It is obvious from archive materials that there is a relatively unusual system of cellars in the locality. They are atypical in shape and sectional view. They appear to be walled up older corridors, and do not correspond to the present houses, and extend beyond them. It can be assumed that there can be remnants of unused corridors in the area, which were probably provided with simple wooden support or lacked it totally. Similar systems are known especially in Germany. Within the territory of the Czech Republic the literature (Hašek, Unger 2001) mentions the existence of lochs in Pouzdřany, which were used as temporary hiding places by village inhabitants. It is a system of narrow, winding and branching corridors, in some places widened so the people could dwell there temporarily. The corridors were built in an appropriate environment (e.g. loess) and did not reach too far. The underground spaces lacked any kind of reinforcement and their total length was several tens of meters. It is, however, impossible to produce reliable evidence for such a hypothesis. But if we consider the fact that the Kostelní street was, before its reinforcement, a sunken road, which was rather deep, rutted and hollowed out by water, the corridors and possibly also the lochs could have led not only from the foot of the hill southwards but also from this sunken road. The evidence for this could be a slight indication of such an entrance close to surface approximately in front of the driveway into the neighbouring house, but such evidence is unfortunately not very conclusive. When the cellars were being built, the unwanted spaces could have been walled in or buried. Indications of this activity can be found in cellars. Corridors that were not buried and were boarded only partly or not at all, and especially the ones that crossed and branched, were then subject to gradual destruction, which manifested itself on the surface by either slow subsidence or gradual collapsing up to the surface, example of which appears to be the collapse of the yard surface of the house in question.

Investigation did not discover any entrance into the underground space. The range of desirable investigation exceeded our possibilities to conduct research. Clear evidence of the existence of a cavity however appears to be the penetrating stick and the draught of the fuggy air. Coaction of water cannot be totally excluded either; it could run through the underground spaces during floods. Partial interconnection with the sewerage system is a possibility, too, even though such a sudden rush of sewerage waters would probably also reveal itself in the surrounding cellars. The volume of sunken earth is large, estimated to be dozens of $\mathrm{m}^{3}$, given the widening of the cavern under the talus and by the thickness of the talus (more than $4 \mathrm{~m}$ ). It can be inferred that the ceiling of the original cavity was 2.9 to $3.3 \mathrm{~m}$ deep, while the bottom was located at a depth of around $6.5 \mathrm{~m}$. The extent of the structure cannot be defined. If the cavity was really a loch, then the size would be approximately $2 \times 3 \mathrm{~m}, 2.5 \times 4 \mathrm{~m}$ at a maximum. A larger cavity without solid timbering in not very cohesive soils would be buried in a short time. A research of the surrounding area would be quite expensive, however, more similar spaces can be assumed in the vicinity. Soundings from the street can be considered in places where indications of continuing corridors appear, or difficult and dangerous excavation in the place of the collapse or opening and mapping of the walled-up cellars. 


\section{Conclusion}

An old system of underground structures probably exists in the vicinity. It appears to be narrow, winding and branching corridors, part of which was subsequently used for building bricked cellars. The original system of the underground corridors was not lagged it is however possible that it could be provided by simple wooden support. No vaulted underground spaces were discovered during investigation, except for those related to modern activity. The creation of the vaulting is very distinctive in the rock environment, which excludes the possibility of a collapse in the yard due to the breaking of the vault. A more probable assumption is that the unemployed cavities were partly buried and walled up. Investigations revealed a draught of unknown origin, proving that the system is still interconnected (defective walling up of the cellars or a sewerage system). The extent and direction of the cavity into which the base of the yard collapsed cannot yet be determined. It can be assumed that it is system of quite narrow corridors, widened to $2 \mathrm{~m}$ to $2.5 \mathrm{~m}$ at the maximum, however, the floors of the underground spaces could have be deepened by running water in the past. The collapse of the yard's base appears to be gradual, with partial plastic flow (sinking). It is also possible that the paving itself, thanks to its firmness, was able to hold the normal load and the collapse was not caused directly by the cavern. Since the existence of lochs is documented in this area, it cannot be excluded that this structure is also a loch. The existence of similar objects in the vicinity can be expected.

\section{Acknowledgement}

This article was prepared within the scope of Research Project VZ MSM 0021630519.

\section{References}

BÁLEK, M., BERKOVEC, T., KOS, P., LEČBYCH, M., MATĚJÍČKOVÁ, A., PARMA, D., PŘichYSTAL, M., ŠMíD, M. 2003: Předběžné výsledky první etapy záchranného archeologického výzkumu v trase dálnice D1 Vyškov - Mořice. Přehled výzkumů 44, Brno, 137-150.

ČERNOHORSKÝ, K. 1941: Moravská lidová keramika. Otto. Praha.

ČERNÝ, E. 1992: Výsledky výzkumu zaniklých středověkých osad a jejich plužin. Vlastivědná knihovna moravská. Sv. 74. Brno.

ČERVINKA, I. L. 1992: "Lochy", umělé jeskyně na Moravee, Souborný prehled, Zvláštni otisk z "Časopisu moravského musea zemského", ročník 5 , č. 2. Brno.

DOSTÁL, P. 2003: Průzkum propadu dvorku na lokalitě Miroslav. GEODRILL s.r.o. MS, Deposited: Archive of company Geodrill, Brno.

HAŠEK, V., UNGER, J. 2001: Archaeological and Geophysical Prospection in Morava, in the Years 1974 - 2000. Ve službách archeologie III, Brno, 68.

HAŠEK, V., TOMEŠEK, J., UNGER, J. 1998: Archäogeophysikalische Prospektion im Bereich der Archäologischen Grabunstätten im der Wüstung Hard ud der Ehemaligen Burglagen auf der Flue Sand. Arbeitberichte Thaya, $750-752$.

KOS, P. 1995: Prehistorické podzemí na Moravě? Speleo 20, Praha, 50-53.

KOS, P. 2002: Výzkum lochů na Moravě. MS. Master diploma thesis. Derposited: Library of the Faculty of Philosophy, Masaryk University, Brno.

KOS, P. 2005: K moravským lochům. Forum urbes medii aevi (FUMA) II, Brno, 166-183.

MACEK, M. 1997/1998: Überlegungen zum Erdstallproblem in Österreich am Beispiel der Hausberganlage von Althöflein in Niederösterreich. Studie zur Dokumentation, Bauweise, Bewetterung, Funktion und Datierung. MS. Master diploma thesis. Derposited: Library of Institut für Ur- und Frühgeschichte, Wien.

MĚŘÍNSKÝ, Z. 1977: Nález propadnutého "lochu" na zaniklé středověké osadě Řevušín, okr. Brno-venkov. Archeologické rozhledy XXIX, Praha, 203-204.

NEKUDA, V. 1972: Středověká ves Mstěnice. Deset let archeologického výzkumu 1960-1970. Vlastivědný věstník moravský XXIV, 12-45.

NEKUDA, V. 1982: Středověká vesnice na Moravě ve světle archeologických výzkumů, Katalog výstavy. Brno.

NEKUDA, V. 1992: Erdställe in der mittelalterlichen Wüstungen Mährens. Der Erdstall 18, 25-42.

SCHWARZFISCHER, K. 1990: Zur Bauweise der Erdställe - Zweckbauten oder Kultstätten?. Der Erdstall 16, Roding, 5-94.

SKUTIL, J. 1984: Moravské "lochy". Časopis Vlasteneckého muzejního spolku v Olomouci 57, 20-37.

SKUTIL, J. 1949: Soupis lochů na Moravě, Časopis Vlasteneckého muzejniho spolku v Olomouci 58, 3-20.

STUCHLíK, S. 2000: Starší a střední doba bronzová. In: Čižmář, M., Geislerová, K., Unger, J.(Eds.): Výzkumy 1993-1998. Ústav archeologické památkové péče Brno. Brno, 31-35.

UNGER, J. 1987: Podzemní chodby v jihomoravské středověké a novověké vesnici. Archeologica Historica 12, 97-110. 
